\title{
FORMULATION AND IN VITRO STUDY OF PROPRANOLOL HYDROCHLORIDE CONTROLLED RELEASE FROM CARBOXYMETHYL CHITOSAN-BASED MATRIX TABLETS
}

\author{
Hernawan*, Septi Nurhayati, Khoirun Nisa, A.W. Indrianingsih, \\ Cici Darsih, and Muhammad Kismurtono
}

\begin{abstract}
Technical Implementation Unit for Development of Chemical Engineering Processes, Indonesian Institute of Sciences, Jl. Yogya-Wonosari km 32, Gading, Playen, Gunungkidul, Yogyakarta 55861, Indonesia
\end{abstract}

Received March 1, 2013; Accepted August 30, 2013

\begin{abstract}
Formulation and in vitro study of propranolol hydrochloride controlled release from carboxymethyl chitosanbased matrix tablets have been conducted. Formulations with various concentrations of carboxymethyl chitosan $2 \%$ (F1), 4\% (F2), 6\% (F3) were done by wet granulation method. Compatibility test was conducted by XRD and FTIR spectroscopy to determine interaction between propranolol hydrochloride and polymer excipients. Dissolution profiles was obtained through in vitro tests release using simulated gastric fluid (without enzymes, $\mathrm{pH}$ 1.2) for the first $2 \mathrm{~h}$ and followed by simulated intestinal fluid (phosphate buffer solution without enzyme, pH 7.2) for $2 \mathrm{~h}$ remaining. The dissolution profile of each formulation was fitted with five kinetics modeling of drug release (zero order, first order, Higuchi, Peppas-Korsmeyer, and Hixson-Crowell). The compatibility test results showed that formulation caused physical interactions between propranolol hydrochloride and polymer excipient but doesn't make crystallinity nature of propranolol hydrochloride disturbed even after formulation. Dissolution profiles of each formulation showed that controlled release of propranolol hydrochloride from the tablet followed Peppas-Korsmeyer model. It is concluded that carboxymethyl chitosan in appropriate proportions is suitable for formulating propranolol hydrochloride controlled release tablets which exhibit Peppas-Korsmeyer release kinetics.
\end{abstract}

Keywords: carboxymethyl chitosan; matrix tablets; propranolol hydrochloride; controlled release; PeppasKorsmeyer

\section{ABSTRAK}

Telah dilakukan formulasi dan kajian pelepasan terkontrol propranolol hidroklorida dari matrik tablet berbasis karboksimetil kitosan secara in vitro. Formulasi dengan variasi konsentrasi karboksimetil kitosan sebesar $2 \%(F 1)$, $4 \%$ (F2), $6 \%$ (F3) dilakukan dengan metode granulasi basah. Uji kompatibilitas dilakukan dengan XRD dan spektroskopi FTIR untuk mengetahui interaksi antara propranolol hidroklorida dan polimer eksipien. Profil disolusi diperoleh melalui uji invitro menggunakan simulasi cairan lambung (tanpa enzim, pH 1,2) untuk 2 jam pertama dan diikuti simulasi cairan intestinal (larutan buffer phospat tanpa enzim, $\mathrm{pH} \mathrm{7,2)} \mathrm{untuk} 2$ jam berikutnya. Hasil disolusi kemudian dicocokkan dengan lima model kinetika disolusi (orde nol, orde 1, Higuchi, Peppas-Korsmeyer, dan Hixson-Crowell). Hasil uji kompatibilitas menunjukkan bahwa proses formulasi menyebabkan interaksi fisika antara propranolol hidroklorida dan polimer eksipien namun tidak mengganggu kristalinitas propranolol hidroklorida setelah formulasi. Profil disolusi masing masing formulasi menunjukkan bahwa pelepasan propranolol hidroklorida secara terkontrol mengikuti model Peppas-Korsmeyer. Hal ini dapat disimpulkan bahwa karboksi metil kitosan dalam jumlah yang tertentu dapat digunakan untuk formulasi tablet propranolol hidroklorida dengan pelepasan terkontrol dengan kinetika pelepasan Peppas-Korsmeyer.

Kata Kunci: karboksimetil kitosan; matrik tablet; propranolol hidroklorida; pelepasan terkontrol; Peppas-Korsmeyer

\section{INTRODUCTION}

The optimal therapeutic response of many drugs can be observed when adequate blood levels is achieved and maintained with minimal fluctuations. Controlled release or sustained release products became popular for the oral administration of such drugs because they give more consistent blood levels [1].

* Corresponding author.

Email address : hern001@lipi.go.id
Controlled release with zero order release kinetics maintains plasma concentration of such types of drugs at constant level for better effect. An ideal controlled release tablet should release the required quantity of drug with predetermined kinetics in order to maintain effective drug plasma concentration. To achieve constant drug plasma concentration, tablet should be formulated in such that it can release the drug in a

Hernawan et al. 
Table1. Composition of various tablet formulations

\begin{tabular}{cccccccc}
\hline $\begin{array}{c}\text { Formulation } \\
\text { code }\end{array}$ & $\begin{array}{c}\text { Drug } \\
(\mathrm{mg})\end{array}$ & $\begin{array}{c}\text { CMCh } \\
(\mathrm{mg})\end{array}$ & $\begin{array}{c}\text { CMC-Na } \\
(\mathrm{mg})\end{array}$ & $\begin{array}{c}\text { Xantan gum } \\
(\mathrm{mg})\end{array}$ & $\begin{array}{c}\text { Lactose } \\
(\mathrm{mg})\end{array}$ & $\begin{array}{c}\text { Mg-stearate } \\
(\mathrm{mg})\end{array}$ & $\begin{array}{c}\text { Total weight } \\
(\mathrm{mg})\end{array}$ \\
\hline F1 & 120 & 6 & 24 & 100 & 46 & 4 & 300 \\
F2 & 120 & 12 & 24 & 100 & 40 & 4 & 300 \\
F3 & 120 & 18 & 24 & 100 & 34 & 4 & 300 \\
\hline
\end{tabular}

predetermined and reproducible manner.

1-isopropylamino-3-(1-napthyloxy)-2-propanol hydro chloride or propranolol hydro chloride is nonselective $\beta$ adrenergic blocking agent and it has been used as an antihypertensive drug and used for treatment of angina pectoris, and that of many other cardiovascular disorders [2-6]. Because of its relatively short plasma half-life, patients are routinely asked to take propranolol hydrochloride in divided daily doses, once every 6 to $8 \mathrm{~h}$. Such frequent drug administration may reduce patient compliance and therapeutic efficacy [7]. Propranolol hydrochloride controlled release with zero order release kinetics is needed to improved patient compliance and therapeutic efficacy.

Few methods published describing approaches for controlled release formulations of propranolol hydrochloride. Niranjan Patra et al. developed a bilayer tablet of propranolol hydrochloride using super disintegrant sodium starch glycolate for the fast release layer and water immiscible polymers such as ethyl cellulose, Eudragit RLPO and Eudragit RSPO for the sustaining layer which showed dissolution kinetics followed the Higuchi model via a non-Fickian diffusion [7]. Sanghavi et al. prepared matrix tablets of propranolol hydrochloride using hydroxypropyl methylcellulose (HPMC) which exhibited first order release kinetics [8] and Pandey et al. and Chaturdevi et al. developed a floating tablet using HPMC $[6,9]$. Javadzadeh et al. developed liquisolid tablets which showed zero order release kinetics [10]. Velasco-De-Paola et al. described dissolution kinetics of controlled release tablets containing propranolol hydrochloride prepared using eudragit [11]. Mohammadi-Samani et al. described controlled-release dosage forms of propranolol hydrochloride using coating of ethyl cellulose [12]. Despande and Ganesh, and Huang et al prepared orodispersible tablets employing microcrystalline cellulose [13-14].

Carboxymethyl chitosan is a polymer derived from chitosan, polyaminosaccharide with many significant biological (biodegradable, biocompatible, bioactive) and chemical properties (polycationic, hydrogel, reactive groups such as $\mathrm{OH}$ and $\mathrm{NH}_{2}$ ). All of these properties make chitosan and its derivatives widely used in many biomedical fields. Carboxymethylated chitosan has received more and more attention because of its good water solubility, and it is more convenient to be applied in medicine because it fits the neutral environment of the human body [15-16]. But there is no systematic publication regarding the use of this polymer for the preparation of oral controlled drug delivery systems. Therefore, it is suggested here that this polymer has the potential to develop a controlled release dosage forms such as matrix tablets of high water soluble drugs. Propranolol hydrochloride was selected as a water-soluble drug. This paper describes a formulation and study of propranolol hydrochloride controlled release from carboxymethyl chitosan-based matrix tablets aiming to find out release mechanism by fitted in to various kinetics models (zero order, first order, Higuchi, Peppas-Korsmeyer and Hixson-Crowell).

\section{EXPERIMENTAL SECTION}

\section{Materials}

Propranolol hydrochloride was received from Kimia Farma (Jakarta, Indonesia). Carboxymethyl chitosan (CMCh), hydrochloric acid, magnesium stearate, CMC-Na, xanthan gum and lactose, buffer phosphate 7.2. All the other chemicals used were of analytical grade.

\section{Instrumentation}

Tablets were prepared using single punch tablet compression machine (Reickermann Korsch, Germany). Infrared spectra were recorded with Shimadzu Prestige-21 FTIR Spectrometer. X-ray diffractometry of drug, excipient and formulations were performed using X-Ray diffractometer (Philips x'pert). The drug content was analyzed using Dynamica RB 10 Ultraviolet-visible Spectrophotometer.

\section{Procedure}

\section{Preparation of matrix tablets}

Controlled release matrix-embedded tablets were prepared separately by wet granulation method using different proportions of CMCh $(2 \%, 4 \%$, and $6 \%)$ and denoted as F1, F2, and F3 respectively. The composition of various formulations is given in Table 1. Propranolol hydrochloride, $\mathrm{CMCh}, \mathrm{CMC}-\mathrm{Na}$, xanthan gum and lactose were mixed and homogenized in a cube mixer $90 \mathrm{rpm}$ for $10 \mathrm{~min}$. After completion, $50 \mathrm{~mL}$ of distilled water was added to the mixture to form 
granules. The mixture granules dried at $40-60{ }^{\circ} \mathrm{C}$ for 48 $\mathrm{h}$ and mixed with $1.33 \%$ of magnesium stearate. Tablets were compressed at $300 \mathrm{mg}$ weight on a single punch tablet compression machine (Reickermann Korsch, Germany) fitted with $5 \mathrm{~mm}$ round-shaped punches with compression pressure $10 \mathrm{kN}$ and dwell time $2 \mathrm{~s}$.

\section{Compatibility studies}

The interaction between the drug and polymer was investigated by using Fourier-transform infrared (FTIR) spectroscopy and X-ray powder diffraction (XRD).

Fourier-Transform Infrared Spectroscopy. The samples (propranolol hydrochloride or formulations F1, $\mathrm{F} 2$, and F3) were previously ground and mixed thoroughly with potassium bromide, an infrared transparent matrix, at 1:5 (sample: $\mathrm{KBr}$ ) ratio, respectively. The $\mathrm{KBr}$ discs were prepared by compressing the powders at a pressure of 5 tons for 5 $\mathrm{min}$ in a hydraulic press. Forty scans were obtained at a resolution of $4 \mathrm{~cm}^{-1}$, from 4,000 to $300 \mathrm{~cm}^{-1}$. FTIR spectra were obtained by using Shimadzu Prestige-21 FTIR Spectrometer.

X-ray powder diffraction. X-ray diffractogram of drug, excipient and formulations were performed using X-Ray diffractometer (Philips x'pert). The cross section of samples was exposed to $\mathrm{x}$-ray radiation $(\mathrm{Cu} \mathrm{Ka})$ with wavelength of $1.5406 \mathrm{~A}$. The rate of the scanning was $0.6^{\circ} / \mathrm{min}$ at a range of $5-50^{\circ} 2 \theta$. Samples, ground into powders with an agate mortar and pestle, were measured on a low background quartz plate in an aluminum holder.

\section{Evaluation of Tablets}

Physical properties of tablets. The drug content of the manufactured tablets was determined. From each batch 20 tablets were taken, weighed, and finely ground. An adequate amount of this powder equivalent to $10 \mathrm{mg}$ of drug was accurately weighed, suitably dissolved and diluted in distilled water and analyzed by ultraviolet (UV) spectrophotometric method at $290 \mathrm{~nm}$. The tablets were also evaluated for weight variation $(n=20)$, hardness $(n=6)$, and friability. Hardness was determined by using a Monsanto tablet hardness tester (Stokes Monsanto, Germany). Friability test was conducted using Erweka friabilator abrasive tester (Erweka TA 20, Germany).

In vitro drug release. Drug release was assessed by dissolution test under the following conditions: on the USP dissolution apparatus (Erweka DT 600, Germany) at $50 \mathrm{rpm}$ in $900 \mathrm{~mL}$ of simulated gastric fluid (without enzyme, $\mathrm{pH}$ 1.2) for the first $2 \mathrm{~h}$ and followed by simulated intestinal fluid (without enzyme, $\mathrm{pH}$ 7.2) for the remaining hours. The temperature was maintained at $37 \pm 0.5^{\circ} \mathrm{C}$. The amount of propranolol hydrochloride was $120 \mathrm{mg}$ in all formulations. Five milliliters of the sample was withdrawn by using a syringe filter $(0.45 \mu \mathrm{m})$ at regular intervals and replaced with the same volume of prewarmed $\left(37 \pm 0.5^{\circ} \mathrm{C}\right)$ fresh dissolution medium. The drug content in each sample was analyzed after suitable dilution using UV spectrophotometer method at 290 nm (Dynamica RB 10).

In the model-dependent approaches, the release data were fitted to five kinetic models including the zero order (Eq. 1), first order (Eq. 2), Higuchi matrix (Eq. 3), Peppas-Korsmeyer (Eq. 4) and Hixson-Crowell (Eq. 5) release equations to find the fit equation. $R=k_{1} t$

$\log U R=\frac{k_{2} t}{2.303}$

$R=k_{3} \sqrt{t}$

$\log R=\log _{4}+n \log t$

$\sqrt[3]{U R}=k_{5} t$

where $R$ and $U R$ are the released and unreleased percentages, respectively, at time $(t) ; k_{1}, k_{2}, k_{3}, \mathrm{k}_{4}$, and $k_{5}$ are the rate constants of zero-order, first-order, Higuchi models, Peppas-Korsmeyer, and HixsonCrowell model, respectively.

\section{RESULT AND DISCUSSION}

\section{Compatibility Studies}

Propranolol hydrochloride and excipients interaction was analyzed by comparing the IR spectra of the physical mixture of drug with the excipients used with the IR spectra of pure propranolol hydrochloride and spectra of pure carboxymethyl chitosan. As shown in Fig. 1, propranolol hydrochloride gives peaks in IR spectrum nearby at $2962 \mathrm{~cm}^{-1}$ due to the presence of a secondary amine group, $3286 \mathrm{~cm}^{-1}$ due to the hydroxyl group (secondary), the aryl alkyl ether displays a stretching band at $1103 \mathrm{~cm}^{-1}$ and the peak at $771 \mathrm{~cm}^{-1}$ due to a-substituted naphthalene [7]. Carboxymethyl chitosan gives peaks in IR spectrum nearby $3441 \mathrm{~cm}^{-1}$ due to the hydroxyl group. The IR spectra of the physical mixture showed broadening of peaks at 3325 $\mathrm{cm}^{-1}$ due to the extensive hydrogen bonding. Major frequencies of functional groups of pure propranolol hydrochloride remained in physical mixture containing excipients. Hence, there was no major interaction between the propranolol hydrochloride and excipients used in the study. Mentioned evidences thus lead to the conclusion that changes seen are as a result of physical interaction between the propranolol hydrochloride and excipients.

The X-ray powder diffractograms of pure propranolol hydrochloride and formulations (Fig. 2) were measured for comparison. Pure propranolol hydro 


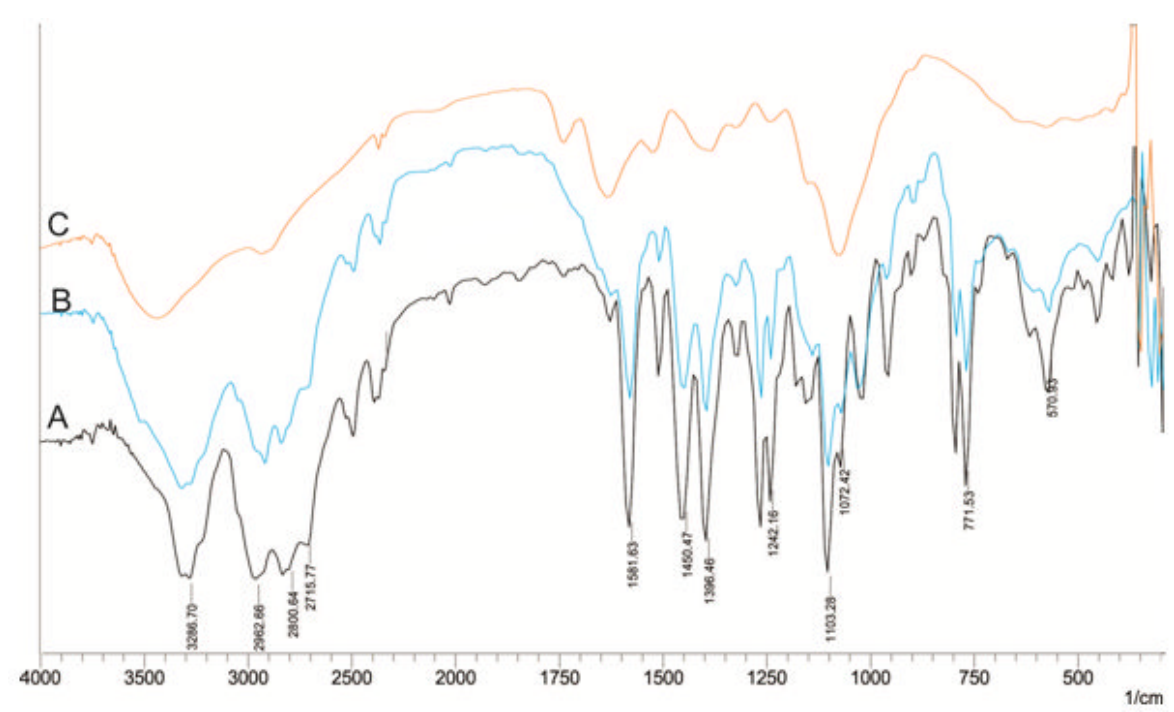

Fig 1. FTIR spectrograms of pure propranolol hydrochloride (A), formulation (B), pure CMCh (C)

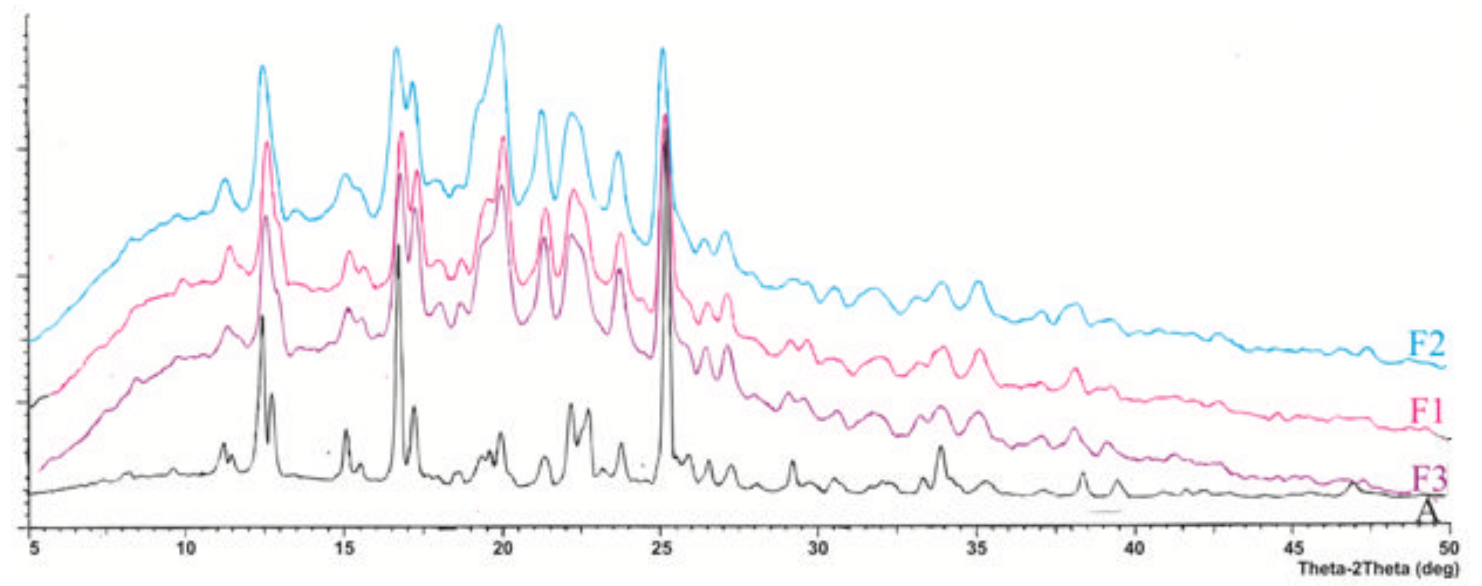

Fig 2. X-ray powder diffractograms of pure propranolol hydrochloride (A), F1 (B), F2 (C) and F3 (D)

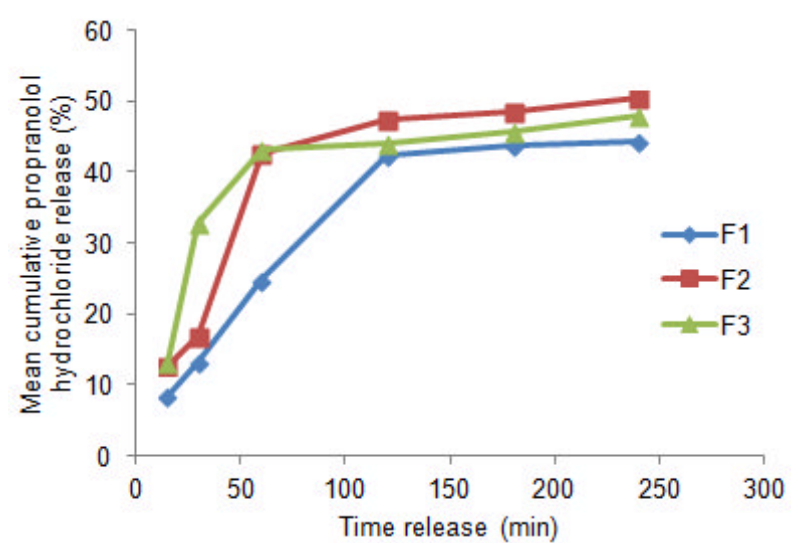

Fig 3. Dissolution profile of propranolol hydrochloride

chloride showed a typical pattern of crystalline substance which showed characteristic sharp defraction peaks at $12.54^{\circ}, 16.76^{\circ}, 17.23^{\circ}, 19.92^{\circ}, 23.68^{\circ}$ and $25.12^{\circ}$. These corresponds to X-ray diffraction patterns of polymorphs of two crystalline forms mixture of propranolol hydrochloride as reported by Bartolomei et al. [17] and Javadzadeh [10]. The sharp peaks of drug were also present in the formulations, where it was mixed with excipients used in the study. This indicated crystalline nature of propranolol hydrochloride was not disturbed even after formulation [7-9,18].

It is important to study polymorphic changes of propranolol hydrochloride in the formulations, because polymorphic changes of the drug are important factors that may affect the dissolution rate and bioavailability. Furthermore, polymorphisms also influence the therapeutic efficacy of the drug and the pharmaceutical implication of the presence of meta stable crystalline forms in the bulk powder. In addition, crystal structure could affect tablet porosity and density, the mechanism of disintegration and aggregation, as well as the plastic and elastic properties of solid dosage forms [10]. 
Table 2. Physical properties of compressed tablets

\begin{tabular}{|l|c|c|c|}
\hline Formulation code & $\mathrm{F} 1(2 \% \mathrm{CMCh})$ & $\mathrm{F} 2(4 \% \mathrm{CMCh})$ & $\mathrm{F} 3(6 \% \mathrm{CMCh})$ \\
\hline Weight variation & $302.00 \pm 6.96$ & $304.66 \pm 7.93$ & $306.50 \pm 4.50$ \\
\hline Hardness $\left(\mathrm{kg} / \mathrm{cm}^{2}\right)$ & $6.50 \pm 1.50$ & $6.20 \pm 2.30$ & $6.70 \pm 1.70$ \\
\hline Friability $(\%)$ & $0.06 \pm 0.02$ & $0.09 \pm 0.02$ & $0.43 \pm 0.14$ \\
\hline Water content $(\%)$ & $2.00 \pm 1.50$ & $2.00 \pm 0.35$ & $2.00 \pm 0.78$ \\
\hline
\end{tabular}

Table 3. Statistical parameters of various formulations after fitting drug release data into various release kinetics models

\begin{tabular}{lcccccc}
\hline \multirow{2}{*}{ Kinetic models } & \multicolumn{2}{c}{$\mathrm{F} 1(2 \% \mathrm{CMCh})$} & \multicolumn{2}{c}{$\mathrm{F} 2(4 \% \mathrm{CMCh})$} & \multicolumn{2}{c}{$\mathrm{F} 3(6 \% \mathrm{CMCh})$} \\
\cline { 2 - 7 } & $\mathrm{R}$ & $\mathrm{k}$ & $\mathrm{R}$ & $\mathrm{k}$ & $\mathrm{R}$ & $\mathrm{k}$ \\
\hline Zero-order & 0.908 & $2.0 \times 10^{-3}$ & 0.827 & $2.0 \times 10^{-3}$ & 0.748 & $1.0 \times 10^{-3}$ \\
First-order & 0.918 & $5.0 \times 10^{-4}$ & 0.847 & $5.0 \times 10^{-4}$ & 0.781 & $5.0 \times 10^{-3}$ \\
Higuchi & 0.958 & $4.4 \times 10^{-1}$ & 0.896 & $4.3 \times 10^{-1}$ & 0.830 & $3.1 \times 10^{-1}$ \\
Peppas-Korsmeyer & 0.978 & $1.1 \times 10^{-1}$ & 0.933 & $3.8 \times 10^{-1}$ & 0.857 & 1.285 \\
Hixson-Crowell & 0.914 & $5.0 \times 10^{-5}$ & 0.840 & $5.0 \times 10^{-5}$ & 0.770 & $5.0 \times 10^{-4}$ \\
\hline
\end{tabular}

\section{Evaluation of Tablets}

\section{Physical properties of tablets}

The results of the uniformity of weight, hardness, drug content, water content and friability of the tablets are given in Table 2. Weight variations test showed that all of the samples are not more than $7.50 \%$, it was compliant with the official requirements of weight uniformity [19]. Friability test result showed that friability all of the samples ranged between $0.06-0.43 \%$. Friability tablets must not be more than $0.8 \%$ but losing weight or friability less than $0.5-1 \%$ can still be justified [20]. The low friability indicates that the matrix tablets are compact and hard. The results were reproducible, even on tablets that had been stored for about 6 months at $25^{\circ} \mathrm{C}$ and $60 \%$ relative humidity.

\section{Release rate studies}

In-vitro dissolution studies were conducted on three tablets of each of the formulations such as F1, F2 and F3. The mean cumulative of propranolol hydrochloride released at different time for each formulation is shown in Fig. 3. Table 3 shows the regression parameters obtained after fitting the in vitro dissolution data to various release kinetic models. The goodness of fit for various models investigated for formulations containing carboxymethyl chitosan ranked in order of KorsmeyerPeppas > Higuchi > First order > Hixson-Crowell $>$ Zero order. In vitro release data of propranolol hydrochloride from carboxymethyl chitosan based matrixs tablet was best fitted to Korsmeyer-Peppas model. The mechanism of drug release was also observed from the $n$ (the exponential diffusion value) obtained from KorsmeyerPeppas equation. Formula F1 and F2 respectively have an $n$ value 0.644 and 0.529 , suggesting that the two formulas followed non-Fickian diffusion transport mechanism (anomalous diffusion) which is a combination of diffusion and erosion mechanisms [21].
While the $\mathrm{F} 3$ has a value of $\mathrm{n}$ of 0.394 , which means diffusion followed Fickian diffusion transport mechanism.

\section{CONCLUSION}

The matrix embedding technique using carboxymethyl chitosan has successfully extended the release of propranolol hydrochloride. It is particularly suitable for wet granulation method to obtained controlled-release tablets with appropriate standards and well reproducible drug release profiles. It is concluded that carboxymethyl chitosan in appropriate proportions is suitable for formulating propranolol hydrochloride controlled release tablets which exhibit Peppas-Korsmeyer release kinetics.

\section{ACKNOWLEDGEMENT}

The authors would like to express their gratitude to Prof. Dr. Lukman Hakim, APU, Head of Indonesian Institute of Sciences for the useful comment. The study was supported by Improvement the Ability of Researchers and Engineers Incentives Project of the Ministry of State for Research and Technology Republic of Indonesia.

\section{REFERENCES}

1. Sahoo, J., Murthy, P.N., Biswal, S., Sahoo, S.K., and Mahapatra, A.K., 2008, AAPS PharmSciTech. 9, 2, 577-582.

2. Martindale W.H., 1993, The Extra Pharmacopeia, $30^{\text {th }}$ ed., Pharmaceutical, London, 1783.

3. Korolkovas, A., 1988, Essentials of Medicinal Chemistry, $2^{\text {nd }}$ ed., Wiley, New York, 435.

4. Patel Monali, D., and Gevariya, H.B., 2012, World J. Pharm. Res., 1, 1, 120-127. 
5. Patel, R., Patel, H., and Patel, G., 2010, Webmed Central Pharm. Sci., 1, 10,1-14.

6. Pandey, S., Devmurari, V., Paridhi, S., and Mahalaxmi, R., 2010, Der Pharmacia Lettre, 2, 1, 75-86.

7. Patra, C.N., Kumar, A.B., Pandit, K.H., Singh, S.P., and Devi, M.V., 2007, Acta Pharm., 57, 479-489.

8. Sanghavi N.M., Sarawade V.B., Kamath P.R., and Bijilani C.P., 1998, Indian Drugs, 26, 8, 404-407.

9. Chaturdevi, K., Umadevi, S., and Vaghani, S., 2010, Sci. Pharm., 78, 4, 927-939.

10. Javadzadeh, Y., Musaalrezaei, L., and Nokhodchi, A., 2008, Int. J. Pharm., 362, 1-2, 102-108.

11. Velasco-De-Paola, M.V.R., Santoro, M.I.R.M., and Gai, M.N., 1999, Drug Dev. Ind. Pharm., 25, 4, 535-541.

12. Mohammadi-Samani, S., Adrangui, M., SiahiShadbad, M.R., and Nokhodchi, A., 2000, Drug Dev. Ind. Pharm., 26, 1, 91-94.

13. Deshpande, K.B., and Ganesh, N.S., 2011, Int. J. Res. Pharm. Biomed. Sci., 2, 2, 529-534.
14. Huang, Y-B., Tsai, Y-H., Yang, W-C., Chang, J-S, Wu, P-C., and Takayama, K., 2004, Eur. J. Pharm. Biopharm., 58, 3, 607-614.

15. Zhang, L., Guo, J., Peng, X., and Jin, Y., 2004, J. Appl. Polym. Sci., 92, 2, 878-882.

16. Chen, X-G., and Park, H-J., 2003, Carbohydr. Polym., 53, 4, 355-359.

17. Bartolomei, M., Bertocchi, P., Ramusino, M.C., Santucci, N., and Valvo, L., 1999, J. Pharm. Biomed. Anal., 21, 2, 299-309.

18. Sahoo, S.K., Mallick, A.A., Barik, B.B., and Senapati, P.Ch., 2005, Trop. J. Pharm. Res. 4, 1, 369-375.

19. Anonymous, 1995, Farmakope Indonesia, $4^{\text {th }}$ ed., Ministry of Health Republic of Indonesia, Jakarta.

20. Lieberman, H.A., Lachman, L., and Kanig, J.L. (Eds), The Theory and Practice of Industrial Pharmacy, $2^{\text {nd }}$ ed., Lea and Febiger, Philadelphia 321-340.

21. Pratiwi, M., and Hadisoewignyo, L., 2010, Indo. J. Pharm., 21, 4, 285-295. 